\title{
Jugular versus Mammary Vein Acid-Base Balance, Blood Gases, Hematobiochemical Profiles and Inflammation Biomarkers in Goats with Acute Mastitis
}

\author{
Tharwat $\mathrm{M}^{*}$, Al-Sobayil $\mathrm{F}$ and Almundarij T \\ Department of Veterinary Medicine, College of Agriculture and Veterinary Medicine, Qassim University, Qassim, \\ Saudi Arabia
}

*Corresponding author: Tharwat M, Department of Veterinary Medicine, College of Agriculture and Veterinary Medicine, Qassim University, Qassim, Saudi Arabia, E-mail: mohamedtharwat129@gmail.com

Citation: Tharwat M, Al-Sobayil F, Almundarij T (2017) Jugular versus Mammary Vein Acid-Base Balance, Blood Gases, Hematobiochemical Profiles and Inflammation Biomarkers in Goats with Acute Mastitis. J Vet Sci Ani Husb 5(2): 201. doi: 10.15744/2348-9790.5.201

Received Date: March 08, 2017 Accepted Date: May 22, 2017 Published Date: May 24, 2017

\begin{abstract}
The objectives of this study was to investigate the acid-base balance, blood gases, hematobiochemical profiles and the inflammation biomarkers fibrinogen, serum amyloid A (SAA) and haptoglobin ( $\mathrm{Hp})$ in the mammary and jugular veins of goats with mastitis. Blood samples were collected from the jugular and mammary veins from 26 goats with mastitis and from 10 healthy lactating goats. In diseased goats, the affected quarter had a remarkable degree of swelling, hard and sore to touch; the milk was bloody. In the jugular vein of diseased goats, the values of $\mathrm{PCO}_{2}, \mathrm{PO}_{2}$, base excess $(\mathrm{BE}), \mathrm{HCO}_{3}$ and $\mathrm{TCO}_{2}$ were significantly lower than in the jugular vein of controls. In the mammary vein, the $\mathrm{pH}$ was significantly lower than in controls and the values of $\mathrm{PCO}_{2}, \mathrm{BE}, \mathrm{HCO}_{3}$ and $\mathrm{TCO}_{2}$ were significantly lower than in the controls. In contrast, the $\mathrm{PO}_{2}$, lactic acid and anion gap values were significantly higher in the mammary vein than in controls. The RBCs was significantly lower in the jugular and mammary veins than in controls. In the jugular and mammary veins, albumin concentration was significantly lower than controls. The serum concentrations of calcium and phosphorus were significantly lower in the jugular vein than controls. The serum concentration of fibrinogen did not differ significantly in the jugular and mammary veins compared to healthy controls. In the jugular and mammary veins, the serum concentrations of SAA and Hp were significantly higher than controls. In diseased animals, the serum concentrations of SAA were significantly higher in the mammary veins than in jugular vein. In conclusion, the blood gases, acid-base, hematobiochemical profiles and inflammation biomarkers in the mammary vein goats with acute mastitis could be used as by veterinarians and researchers as reference values for investigation of goats with mastitis and healthy lactating goats.

Keywords: Acute Phase Proteins; Goat; Inflammation; Mastitis; Biomarkers
\end{abstract}

\section{Introduction}

Inflammation of the mammary gland (mastitis) usually occurs primarily in response to intramammary bacterial infection, but also to intramammary mycoplasmal, fungal, or algal infections. Mechanical trauma, thermal trauma, and chemical insult predispose the gland to intramammary infection. The incidence of mastitis depends on the interaction of host, agent, and environmental factors. Acute bovine mastitis involves an initial phase, which includes an inflammatory reaction, and a resolution phase [1].

In goats, inflammation of the mammary gland is a broad diagnosis that may be based on changes in the physical characteristics of the udder or its secretion [2]. In sheep and goats, mastitis is the most common disease in all intensive systems worldwide. The clinical manifestations of mastitis in sheep and goats ranges from peracute gangrenous mastitis with severe illness and toxemia to chronic mastitis and abscess formation without prominent signs [3]. In addition, chronic mastitis is a fundamental cause of culling in meat-producing with reduced lactation in both sheep and goats $[2,3]$.

In biochemical analyses, the blood sampling site strongly influences the measured blood variables and therefore has to be considered in the interpretation. In cattle, the biochemical analyses of mammary vein variables versus jugular vein was reported recently that could provide valuable clinical information and facilitate appropriate medical and surgical treatments [4-6].

The acute phase proteins (APPs) are blood proteins that can be used to assess the systemic response of the innate immune system to infection, inflammation or trauma [7-9]. In ruminants, the APPs have been proposed as sensitive and rapid indicators of inflammatory disturbances [10-12]. The major APPs in ruminants are haptoglobin (Hp) and serum amyloid A (SAA) [7]. In 
cattle, Hp and SAA are effective in the diagnosis and prognosis of mastitis, enteritis, peritonitis, pneumonia, endocarditis, and endometritis $[7,8,13]$. It has also been suggested that APPs may be useful in the assessment of animal welfare $[7,8,10,14]$.

To the authors' knowledge, the acid-base balance, blood gases, hematobiochemical profiles as well as inflammation biomarkers were not estimated in the mammary vein of goats with acute mastitis. The purpose of this study was therefore to investigate these variables in blood samples collected from the jugular and mammary veins of goats with mastitis compared to control healthy lactating goats.

\section{Materials and Methods}

\section{Animals and Clinical Examination}

The experimental protocol was approved by the Animal Ethical Committee, Deanship for Scientific Research, Qassim University, Saudi Arabia. Twenty-six does (age; $25.1 \pm 4.7 \mathrm{mo}$; weight $49.8 \pm 18.6 \mathrm{~kg}$ ) clinically affected with acute mastitis were used. Animals were referred because of anorexia, swelling and gangrene of the mammary gland, abnormal milk secretion and recumbency. Duration of the disease/symptoms ranged from 1 to 7 days. No treatment intervention was attempted. All animals underwent a thorough physical examination, which included general behavior and condition, auscultation of the heart, lungs, rumen and intestine, measurement of heart rate, respiratory rate and rectal temperature, swinging auscultation, percussion auscultation of both sides of the abdomen and rectal examination. Parallel, a control group (age; $21.1 \pm 6.5 \mathrm{mo}$; weight $52.4 \pm 14 \mathrm{~kg}$ ) comprised of ten clinically healthy lactating does were used. All procedures followed were in accordance with the Laboratory Animal Control Guidelines of Qassim University, which basically conform to the Guide for the Care and Use of Laboratory Animals of the National Institutes of Health in the USA (NIH publications No. 86 to 23, revised 1996).

\section{Blood Sampling}

From each doe in diseased and control group, twelve $\mathrm{mL}$ jugular blood sample was collected just before, and a similar volume of blood was collected from the mammary vein. Of both jugular and mammary vein blood samples in the diseased and control goats, two $\mathrm{mL}$ were collected in EDTA tubes for hematological analyses, two $\mathrm{mL}$ in heparinised tubes for blood gas analyses, two $\mathrm{mL}$ in citrated tubes for plasma fibrinogen measurement, and the remaining six $\mathrm{mL}$ in plain tubes to obtain serum for the determination of the biochemical parametsrs and APPS Hp and SAA. Both the third and fourth blood samples were centrifuged at $1200 \times \mathrm{g}$ for $15 \mathrm{~min}$ and the citrated plasma and serum samples obtained were aliquotted in tubes and immediately stored at $-20^{\circ} \mathrm{C}$ pending the clinical chemistry analyses.

\section{Blood gas analyses}

The heparinized blood samples were used immediately to analyse the acid-base and blood gas parameter values in situ using a portable clinical veterinary analyser (i-STAT ${ }^{\circ}$, Abaxis, California, USA). In this way, blood $\mathrm{pH}$, partial pressure of carbon dioxide $\left(\mathrm{PCO}_{2}\right)$, oxygen partial pressure $\left(\mathrm{PO}_{2}\right)$, bicarbonate $\left(\mathrm{HCO}_{3}\right)$, total carbon dioxide $\left(\mathrm{TCO}_{2}\right)$, base excess $(\mathrm{BE})$, oxygen saturation $\left(\mathrm{SO}_{2}\right)$, sodium, potassium, chloride and lactate were analysed immediately in order to prevent changes in the concentrations of these parameters.

\section{Hematology and Serum Biochemistry}

Hematological examinations [total and differential leukocyte count, red blood cells (RBC), hemoglobin, hematocrit, mean corpuscular volume (MCV), mean corpuscular hemoglobin (MCH) and mean corpuscular hemoglobin concentration (MCHC)] were carried out using an automated analyser (VetScan HM5, Abaxis, California, USA). The serum samples were used to determine the concentrations of total protein, albumin, globulin, blood urea nitrogen (BUN), calcium, phosphorus, magnesium and glucose. The serum activity of aspartate aminotransferase (AST), $\gamma$-glutamyl transferase (GGT), alkaline phosphatase (ALP) and creatine kinase (CK) was also measured. An automated biochemical analyser (VetScan VS2, Abaxis, California, USA) was used for the measurement of the above-mentioned serum parameters.

\section{Inflammation biomarkers assays}

The APPs Hp and SAA were measured in the serum samples with validated methods for goats as previously recorded [15-18]. Serum concentrations of Hp were quantified by spectrophotometric method using a commercial kit based on the peroxidase activity of the haptoglobin-hemoglobin complex (Phase Haptoglobin Assay, Tridelta Development Ltd., Ireland). The analytical sensitivity of the assay was $0.15 \mu \mathrm{g} / \mathrm{mL}$, and the intra- and inter-assay CVs were $5-6 \%$ and $4-6 \%$, respectively. Serum concentrations of SAA were determined using a commercially available enzyme-linked immunosorbant assay (ELISA) kit (Phase SAA Kit, Tridelta Development Ltd., Ireland) according to the manufacturer's instructions. The analytical sensitivity of the assay was $0.15 \mu \mathrm{g} / \mathrm{mL}$, with intra- and inter-assay CVs of $4.5 \%$ and $6 \%$, respectively. Fibrinogen concentrations were measured with a commercially available ELISA kit validated for use in goats (Life Sciences Advanced Technologies Inc., FL, USA). The analytical sensitivity of the assay was $7.63 \mathrm{ng} / \mathrm{mL}$ (range $15.6-1000 \mathrm{ng} / \mathrm{mL}$ ). 


\section{Statistical analysis}

Data are presented as means \pm standard deviation, and the analysis was conducted using SPSS program software [19]. Blood gases, hematobiochemical parameters and inflammation biomarkers in the jugular and mammary blood of the diseased goats and of the controls were compared by using the Student's Vtest, and the significance was set at $\mathrm{P}<0.05$.

\section{Results}

Inflammation of the mammary gland occurred within the first $36 \mathrm{hr}$ after parturition. There were a remarkable degree of swelling of the gland and the milk was bloody in 18 cases. There were hemorrhagic patches on the sclera in 5 cases, a severe systemic reaction with elevation of the temperature to $40-42^{\circ} \mathrm{C}$ in all cases, accelerated heart rate to $110-150 \mathrm{bpm}$ in 22 cases, anorexia with profound depression and absence of ruminal movements and muscular weakness in all cases and recumbency within 3-5 hr after the onset of signs in 20 cases. The onsets of local and systemic reactions were sudden. The affected quarter was grossly swollen, hard and sore to touch, and cause severe lameness on the affected side. In 15 cases a bluish discoloration of the affected gland developed as early as hours from the onset of the disease. Gangrene involved the floor of the affected quarter and the whole or part of the teat. Within $24 \mathrm{~h}$, the gangrenous areas became black and ooze serum freely with the formation of blisters. In 7 cases, the gland secretions were reduced to small amount of blood-stained serous fluid without odor, clots or flakes.

Table 1 summarizes the mean blood gases, acid-base and electrolyte parameters of the jugular and mammary veins in the goats with acute mastitis compared to values of same veins in healthy goats. In the jugular vein of diseased goats, the values of $\mathrm{PCO}_{2}$, $\mathrm{PO}_{2}$, base excess, $\mathrm{HCO}_{3}$ and $\mathrm{TCO}_{2}$ were significantly lower than in the jugular vein of controls $(\mathrm{P}<0.05)$. Other parameters did not change significantly. In the mammary vein, the $\mathrm{pH}$ was significantly lower than in controls $(\mathrm{P}<0.05)$ and the values of $\mathrm{PCO}_{2}$, base excess, $\mathrm{HCO}_{3}$ and $\mathrm{TCO}_{2}$ were significantly lower than in the controls $(\mathrm{P}<0.05)$. In contrast, the $\mathrm{PO}_{2}$, lactic acid and anion gap values were significantly higher in the mammary vein than in controls $(\mathrm{P}<0.05)$.

\begin{tabular}{|c|c|c|c|c|}
\hline \multirow{2}{*}{ Parameter } & \multicolumn{2}{|c|}{ Jugular vein } & \multicolumn{2}{c|}{ Mammary vein } \\
\cline { 2 - 5 } & Disease & Control & Disease & Control \\
\hline $\mathbf{p H}$ & $7.447 \pm 0.063^{\mathrm{a}}$ & $7.177 \pm 1.010^{\mathrm{a}}$ & $7.441 \pm 0.053^{\mathrm{a}}$ & $7.494 \pm 0.042^{\mathrm{b}}$ \\
\hline $\mathbf{P C O}_{2}(\mathbf{m m H g})$ & $32.9 \pm 5.8^{\mathrm{a}}$ & $43.0 \pm 5.6^{\mathrm{b}}$ & $32.8 \pm 5.7^{\mathrm{a}}$ & $41.0 \pm 4.8^{\mathrm{b}}$ \\
\hline $\mathbf{P O}_{2} \mathbf{m m H g}$ & $30.9 \pm 2.9^{\mathrm{a}}$ & $33.3 \pm 3.5^{\mathrm{b}}$ & $37.4 \pm 9.2^{\mathrm{a}}$ & $25.3 \pm 5.9^{\mathrm{b}}$ \\
\hline Base Excess (mmol/L) & $-1.3 \pm 4.7^{\mathrm{a}}$ & $4.0 \pm 3.7^{\mathrm{b}}$ & $-1.6 \pm 4.8^{\mathrm{a}}$ & $8.1 \pm 3.6^{\mathrm{b}}$ \\
\hline $\mathbf{H C O}_{\mathbf{3}}(\mathbf{m m o l} / \mathbf{L})$ & $22.8 \pm 4.1^{\mathrm{a}}$ & $28.3 \pm 2.9^{\mathrm{b}}$ & $22.5 \pm 4.3^{\mathrm{a}}$ & $32.0 \pm 4.3^{\mathrm{b}}$ \\
\hline $\mathrm{TCO}_{\mathbf{2}}(\mathbf{m m o l} / \mathbf{L})$ & $23.8 \pm 4.1^{\mathrm{a}}$ & $29.6 \pm 2.9^{\mathrm{b}}$ & $23.5 \pm 4.6^{\mathrm{a}}$ & $32.6 \pm 3.2^{\mathrm{b}}$ \\
\hline Lactic acid $(\mathbf{m m o l} / \mathbf{L})$ & $4.1 \pm 2.4^{\mathrm{a}}$ & $3.7 \pm 2.16^{\mathrm{a}}$ & $3.9 \pm 2.7^{\mathrm{a}}$ & $1.2 \pm 1.0^{\mathrm{b}}$ \\
\hline Sodium $(\mathbf{m m o l} / \mathbf{L})$ & $149 \pm 5^{\mathrm{a}}$ & $147 \pm 1.20^{\mathrm{a}}$ & $148 \pm 5^{\mathrm{a}}$ & $147 \pm 2^{\mathrm{a}}$ \\
\hline Potassium $(\mathbf{m m o l} / \mathbf{L})$ & $4.2 \pm 0.5^{\mathrm{a}}$ & $3.9 \pm 0.3^{\mathrm{a}}$ & $3.8 \pm 0.6^{\mathrm{a}}$ & $3.8 \pm 0.3^{\mathrm{a}}$ \\
\hline Chloride $(\mathbf{m m o l} / \mathbf{L})$ & $111 \pm 6^{\mathrm{a}}$ & $105 \pm 3^{\mathrm{a}}$ & $111 \pm 6^{\mathrm{a}}$ & $104 \pm 3^{\mathrm{b}}$ \\
\hline Anion Gap (mmol/L) & $18.4 \pm 1.6^{\mathrm{a}}$ & $16.9 \pm 2.9^{\mathrm{a}}$ & $18.1 \pm 2.4^{\mathrm{a}}$ & $14.5 \pm 2.1^{\mathrm{b}}$ \\
\hline
\end{tabular}

${ }^{\mathrm{a}, \mathrm{b}}$ Differ significantly $(\mathrm{P}<0.05)$ between diseased and control goats in the same column

Table 1: Blood gases, acid-base and electrolyte parameters (mean \pm SD) in goats with acute mastitis $(n=26)$ compared to healthy controls $(n=10)$

Table 2 shows the mean hematological parameters in the jugular and mammary veins of the goats with acute mastitis compared to values of same veins in healthy goats. In the jugular and mammary veins of diseased goats, red blood cells count was significantly lower than in controls $(\mathrm{P}<0.05)$, however the values of $\mathrm{MCV}$ and $\mathrm{MCH}$ were significantly higher in jugular and mammary veins than in controls $(\mathrm{P}<0.05)$.

Table 3 shows the mean biochemical parameters in the jugular and mammary veins of the goats with acute mastitis compared to values of same veins in healthy goats. In the jugular and mammary veins of diseased goats, albumin concentration was significantly lower than in controls $(\mathrm{P}<0.05)$, however the serum concentration of globulin was significantly higher $(\mathrm{P}<0.05)$. The serum concentration of BUN was significantly higher in the jugular and mammary veins in diseased versus in the controls $(\mathrm{P}<0.05)$. In the jugular vein, the serum concentrations of calcium and phosphorus were significantly lower than controls $(\mathrm{P}<0.05)$.

\begin{tabular}{|c|c|c|c|c|}
\hline \multirow{2}{*}{ Parameter } & \multicolumn{2}{|c|}{ Jugular vein } & \multicolumn{2}{c|}{ Mammary vein } \\
\cline { 2 - 5 } & Disease & Control & Disease & Control \\
\hline White blood cells $(\times \mathbf{1 0} / \mathbf{L})$ & $11.6 \pm 4.7^{\mathrm{a}}$ & $14.4 \pm 2.8^{\mathrm{a}}$ & $14.7 \pm 6.6^{\mathrm{a}}$ & $13.7 \pm 2.5^{\mathrm{a}}$ \\
\hline Lymphocytes $\left(\times \mathbf{1 0}^{\mathbf{9}} / \mathbf{L}\right)$ & $5.1 \pm 3.2^{\mathrm{a}}$ & $5.2 \pm 1.7^{\mathrm{a}}$ & $7.0 \pm 4.5^{\mathrm{a}}$ & $4.6 \pm 1.3^{\mathrm{a}}$ \\
\hline Monocytes $\left(\times \mathbf{1 0}^{\mathbf{9}} / \mathbf{L}\right)$ & $0.1 \pm 0.04^{\mathrm{a}}$ & $0.1 \pm 0.02^{\mathrm{a}}$ & $0.1 \pm 0.1^{\mathrm{a}}$ & $0.1 \pm 0.04^{\mathrm{a}}$ \\
\hline Neutrophils $(\times \mathbf{1 0} / \mathbf{L})$ & $6.4 \pm 4.7^{\mathrm{a}}$ & $10.0 \pm 2.5^{\mathrm{a}}$ & $7.6 \pm 4.4^{\mathrm{a}}$ & $9.0 \pm 2.2^{\mathrm{a}}$ \\
\hline
\end{tabular}




\begin{tabular}{|c|c|c|c|c|}
\hline \multirow{2}{*}{ Parameter } & \multicolumn{2}{|c|}{ Jugular vein } & \multicolumn{2}{c|}{ Mammary vein } \\
\cline { 2 - 5 } & Disease & Control & Disease & Control \\
\hline Red blood cells $\left(\times \mathbf{1 0} \mathbf{1}^{\mathbf{1 2}} / \mathbf{L}\right)$ & $11.5 \pm 2.7^{\mathrm{a}}$ & $17.6 \pm 2.2^{\mathrm{b}}$ & $11.9 \pm 1.6^{\mathrm{a}}$ & $16.2 \pm 1.8^{\mathrm{b}}$ \\
\hline Hemoglobin $(\mathbf{g} / \mathbf{d L})$ & $10.9 \pm 1.3^{\mathrm{a}}$ & $10.3 \pm 1.0^{\mathrm{a}}$ & $10.3 \pm 1.3^{\mathrm{a}}$ & $9.7 \pm 1.0^{\mathrm{a}}$ \\
\hline Hematocrit $(\%)$ & $25.6 \pm 6.0^{\mathrm{a}}$ & $25.8 \pm 2.5^{\mathrm{a}}$ & $26.8 \pm 6.3^{\mathrm{a}}$ & $23.8 \pm 2.6^{\mathrm{a}}$ \\
\hline $\begin{array}{c}\text { Mean corpuscular } \\
\text { volume }(\mathbf{f l})\end{array}$ & $23.2 \pm 6.6^{\mathrm{a}}$ & $15.1 \pm 0.9^{\mathrm{b}}$ & $23.0 \pm 6.2^{\mathrm{a}}$ & $14.9 \pm 1.2^{\mathrm{b}}$ \\
\hline $\begin{array}{c}\text { Mean corpuscular } \\
\text { hemoglobin }(\mathbf{p g})\end{array}$ & $9.5 \pm 2.3^{\mathrm{a}}$ & $5.9 \pm 0.3^{\mathrm{b}}$ & $8.8 \pm 1.7^{\mathrm{a}}$ & $6.1 \pm 0.9^{\mathrm{b}}$ \\
\hline $\begin{array}{c}\text { Mean corpuscular } \\
\text { hemoglobin } \\
\text { concentration }(\mathbf{g} / \mathbf{d L})\end{array}$ & $41.5 \pm 5.3^{\mathrm{a}}$ & $38.9 \pm 0.7^{\mathrm{a}}$ & $40.0 \pm 9.8^{\mathrm{a}}$ & $40.9 \pm 8.4^{\mathrm{a}}$ \\
\hline
\end{tabular}

${ }^{\mathrm{a}, \mathrm{b}}$ Differ significantly $(\mathrm{P}<0.05)$ between diseased and control goats in the same column

Table 2: Hematological parameters (mean \pm SD) in goats with acute mastitis $(n=26)$ compared to healthy controls $(n=10)$

\begin{tabular}{|c|c|c|c|c|}
\hline \multirow{2}{*}{ Parameter } & \multicolumn{2}{|c|}{ Jugular vein } & \multicolumn{2}{c|}{ Mammary vein } \\
\cline { 2 - 5 } & Disease & Control & Disease & Control \\
\hline Total protein (g/L) & $74.3 \pm 11.8^{\mathrm{a}}$ & $76.6 \pm 3.4^{\mathrm{a}}$ & $74.6 \pm 11.5^{\mathrm{a}}$ & $73.0 \pm 2.8^{\mathrm{a}}$ \\
\hline Albumin (g/L) & $31.7 \pm 7.2^{\mathrm{a}}$ & $46.5 \pm 1.9^{\mathrm{b}}$ & $31.6 \pm 7.6^{\mathrm{a}}$ & $46.1 \pm 2.0^{\mathrm{b}}$ \\
\hline Globulin (g/L) & $42.6 \pm 14.1^{\mathrm{a}}$ & $29.9 \pm 2.7^{\mathrm{b}}$ & $43.0 \pm 13.8^{\mathrm{a}}$ & $27.1 \pm 2.2^{\mathrm{b}}$ \\
\hline Blood urea nitrogen (mmol/L) & $11 \pm 7^{\mathrm{a}}$ & $4 \pm 1^{\mathrm{b}}$ & $10 \pm 7^{\mathrm{a}}$ & $4 \pm 1^{\mathrm{b}}$ \\
\hline Aspartate & $161 \pm 97^{\mathrm{a}}$ & $91 \pm 10^{\mathrm{a}}$ & $224 \pm 216^{\mathrm{a}}$ & $85 \pm 9^{\mathrm{a}}$ \\
\hline aminotransferase (U/L) & $63 \pm 41^{\mathrm{a}}$ & $43 \pm 5^{\mathrm{a}}$ & $63 \pm 39^{\mathrm{a}}$ & $41 \pm 5^{\mathrm{a}}$ \\
\hline Alkaline phosphatase (U/L) & $78 \pm 30^{\mathrm{a}}$ & $70 \pm 18^{\mathrm{a}}$ & $76 \pm 26^{\mathrm{a}}$ & $67 \pm 20^{\mathrm{a}}$ \\
\hline Calcium (mmol/L) & $2.2 \pm 0.2^{\mathrm{a}}$ & $2.5 \pm 0.1^{\mathrm{b}}$ & $2.2 \pm 0.2^{\mathrm{a}}$ & $2.3 \pm 0.1^{\mathrm{a}}$ \\
\hline Phosphorus (mmol/L) & $1.6 \pm 0.4^{\mathrm{a}}$ & $1.2 \pm 0.1^{\mathrm{b}}$ & $1.7 \pm 0.4^{\mathrm{a}}$ & $1.4 \pm 0.2^{\mathrm{a}}$ \\
\hline Magnesium (mmol/L) & $0.9 \pm 0.3^{\mathrm{a}}$ & $0.8 \pm 0.1^{\mathrm{a}}$ & $0.9 \pm 0.3^{\mathrm{a}}$ & $0.7 \pm 0.1^{\mathrm{a}}$ \\
\hline Creatine kinase (U/L) & $396 \pm 376^{\mathrm{a}}$ & $240 \pm 25^{\mathrm{a}}$ & $381 \pm 348^{\mathrm{a}}$ & $229 \pm 43^{\mathrm{a}}$ \\
\hline Glucose (mg/dL) & $73 \pm 25^{\mathrm{a}}$ & $100 \pm 29^{\mathrm{a}}$ & $63 \pm 20^{\mathrm{a}}$ & $67 \pm 27^{\mathrm{a}}$ \\
\hline
\end{tabular}

a,b Differ significantly $(\mathrm{P}<0.05)$ between diseased and control goats in the same column

Table 3: Biochemical parameters (mean \pm SD) in goats with acute mastitis $(n=26)$ compared to healthy controls $(n=10)$

Figure 1 shows the serum concentration of fibrinogen in the jugular and mammary veins of the goats with acute mastitis compared to values of same veins in healthy goats. In the jugular and mammary veins, the serum concentration of fibrinogen did not differ significantly compared to healthy controls $(\mathrm{P}>0.05)$. In diseased animals, the serum concentrations of fibrinogen did not differ significantly in the mammary veins than in jugular vein $(\mathrm{P}>0.05)$.

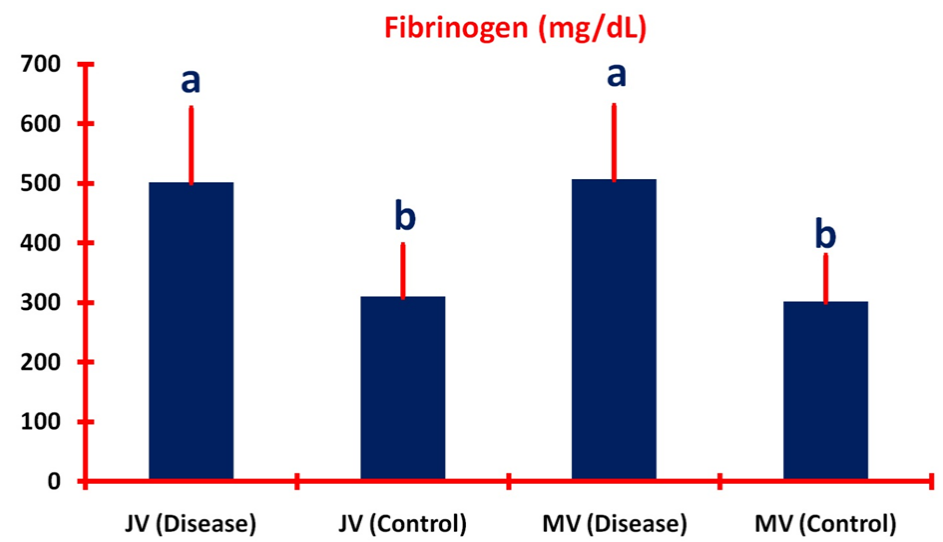

Figure 1: Serum concentrations of fibrinogen in goats with acute mastitis $(n=26)$ compared to healthy controls $(n=10)$; ${ }^{\mathrm{a}, \mathrm{b}}$ Indicate a significant difference $(\mathrm{P}<0.05)$

Figure 2 illustrates serum concentration of SAA in the jugular and mammary veins of the goats with acute mastitis compared to values of same veins in healthy goats. In the jugular and mammary veins, the serum concentrations of SAA was significantly higher than controls $(\mathrm{P}<0.05)$. In diseased animals, the serum concentrations of SAA were significantly higher in the mammary veins than in jugular vein $(\mathrm{P}<0.05)$. 


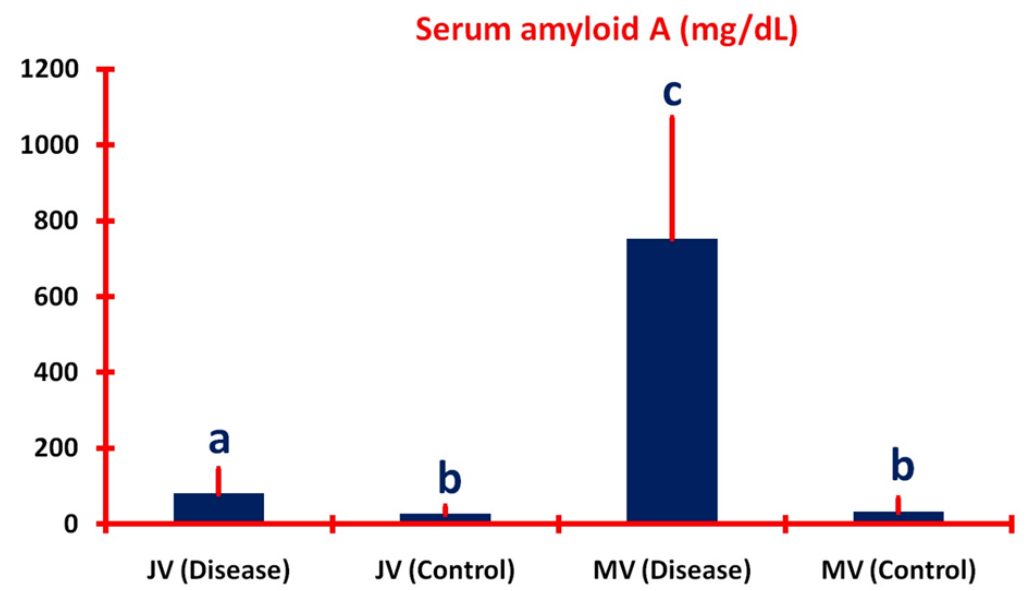

Figure 2: Concentrations of serum amyloid A in goats with acute mastitis $(n=26)$ compared to healthy controls $(n=10) ;{ }^{\mathrm{a}, \mathrm{b}, \mathrm{c}}$ Indicate a significant difference $(\mathrm{P}<0.05)$

Figure 3 illustrates serum concentration of $\mathrm{Hp}$ in the jugular and mammary veins of the goats with acute mastitis compared to values of same veins in healthy goats. In the jugular and mammary veins, the serum concentrations of Hp was significantly higher than controls $(\mathrm{P}<0.05)$. In diseased animals, the serum concentrations of Hp did not differ significantly in the mammary veins than in jugular vein $(\mathrm{P}>0.05)$.

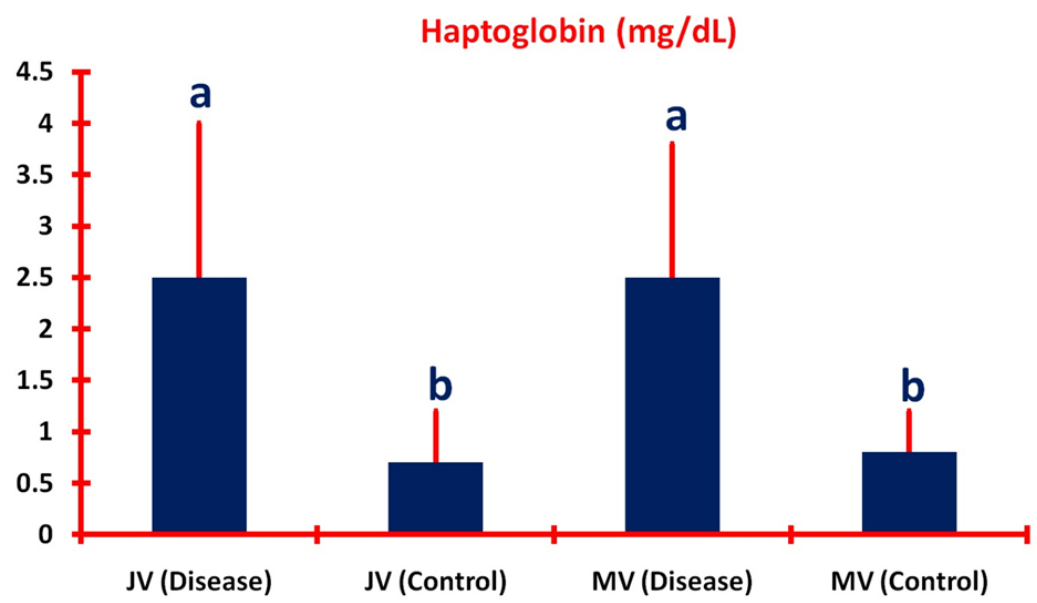

Figure 3: Concentrations of serum haptoglobin in goats with acute mastitis $(n=26)$ compared to healthy controls $(n=10) ;{ }^{\mathrm{a}, \mathrm{b}}$ Indicate a significant difference $(\mathrm{P}<0.05)$

\section{Discussion}

Here, we report, for the first time in animals, the acid-base and blood gas, hematological and biochemical parameters as well as inflammation biomarkers in the mammary vein of goats with acute mastitis compared simultaneously to values in the jugular vein. The results were compared to values in healthy lactating control goats.

In this study, $\mathrm{PCO}_{2}, \mathrm{PO}_{2}$, base excess, $\mathrm{HCO}_{3}$ and $\mathrm{TCO}_{2}$ were significantly lower in the jugular vein of diseased goats than in controls. In the mammary vein, the $\mathrm{pH}$ was significantly lower than in controls and the values of $\mathrm{PCO}_{2}, \mathrm{BE} \mathrm{HCO}_{3}$ and $\mathrm{TCO}_{2}$ were significantly lower than in the controls. In contrast, the $\mathrm{PO}_{2}$, lactic acid and anion gap values were significantly higher in the mammary vein than in controls. The decrease in the $\mathrm{pH}$ of the mammary vein than in controls could be justified by the decreases in $\mathrm{HCO}_{3}$ and $\mathrm{BE}$ values. Other explanation may be the increased serum concentration of lactic acid. The BE represents all basic components, not just $\mathrm{HCO}_{3}$, and as such, is a more sensitive measure of metabolic acidosis than $\mathrm{HCO}_{3}$ alone [20]. Due to inactivity and the recumbency of the goats with mastitis, lactic acid was decreased in the jugular blood. However, there was a markedly increased lactic acid concentration in the mammary blood compared to controls. The increase in the mammary blood lactate concentration could be due to the incapacity of the mammary cells to metabolize all the accumulated pyruvate that should be transformed into lactate, with the aim to produce NAD+ and continue the anaerobic energy production [15].

In the present study, the red blood cells count was significantly lower in the jugular and mammary veins than in controls. The anemic diseased animal may be attributed to the peracute nature of the inflammation and bloody milk secretion [1-3]. As reported early [21], in this study, biochemical abnormalities included hypoalbuminemia, hyperglobulinemia and increased serum BUN concentrations. In the jugular vein, hypocalcemia and hypophosphatemia was noted. 
The acute phase response (APR) is a rapid, nonspecific, systemic response occurring secondary to many types of tissue injury and might be a physiological protective mechanism during inflammatory events [22]. The origin of APR can be attributed to infection, inflammation, surgical trauma, or other causes $[8,9]$. The purpose of the APR is to restore homeostasis and to remove the cause of its disturbance [9]. The APPs are a group of blood proteins that change in concentration in animals subjected to external or internal challenges such as infection, inflammation, surgical trauma, or stress [7]. The changes in APPs due to various inflammatory and non-inflammatory conditions have been studied in many animal species [7,23-27]. In this study, the serum concentrations of the APPs SAA and Hp were significantly higher in both the jugular and mammary veins compared to values of same veins in healthy control goats. The APPs have received attention as biomarkers for APR due to the following facilitating properties: low physiological levels, a fast incline, a marked rise in concentration during APR that eases detection and a fast decline after cessation of a stimulus [9].

\section{Conclusion}

In conclusion, a significant difference was found in the values of blood gases, acid-base balance, hematobiochemical profiles and inflammation biomarkers between the mammary and jugular veins of goats with acute mastitis. It could be used by veterinarians and researchers as reference values for investigation of goats with mastitis and in healthy lactating goats. To the authors' knowledge this is the first report to elucidate the acid-base balance, blood gases, hematobiochemical profiles as well as inflammation biomarkers in the mammary and jugular veins of goats with mastitis compared to values in healthy lactating control goats.

\section{Acknowledgements}

The authors would like to thank N. Peachy, professor of English language, Deanship for Educational Services, Qassim University, for language revisions.

\section{References}

1. Radostits OM, Gay CC, Hinchcliff KW, Constable P (2007) In: Veterinary Medicine. A Textbook of the Diseases of Cattle, Sheep, Pigs, Goats and Horses (10 ${ }^{\text {th }}$ Edn) W.B. Saunders, London.

2. Smith MC, Sherman, DM (2009) Goat Medicine ( $2^{\text {nd }}$ Edn) Wiley-Blackwell, USA.

3. Scott R (2007) Sheep Medicine ( $1^{\text {st }}$ Edn) CRC Press, USA.

4. Wilhelm K, Wilhelm J, Fürll M (2013) Comparative examination of selected blood parameters from different sampling sites in high yielding cows. Practical usability of blood sampling from the udder vein for metabolic analyses. Tierarztl Prax Ausg G Grosstiere Nutztiere 41: 7-14.

5. Samanc H, Kirovski D, Lakić N, Celeska I, Bojković-Kovačević S, et al. (2014) A comparison of the concentrations of energy-balance-related variables in jugular and mammary vein blood of dairy cows with different milk yield. Acta Vet Hung 62: 52-63.

6. Cantalapiedra-Hijar G, Ortigues-Marty I, Lemosquet S (2015) Diets rich in starch improve the efficiency of amino acids use by the mammary gland in lactating Jersey cows. J Dairy Sci 98: 6939-53.

7. Murata H, Shimada N, Yoshioka M (2004) Current research on acute phase proteins in veterinary diagnosis: an overview. Vet J 168: 28-40.

8. Petersen HH, Nielsen JP, Heegaard PM (2004) Application of acute phase protein measurements in veterinary clinical chemistry. Vet Res 35: 163-87.

9. Ceron JJ, Eckersall PD, Martinez-Subiela S (2005) Acute phase proteins in dogs and cats; current knowledge and future perspectives. Vet Clin Pathol 34: 85-99. 10. Eckersall PD (2000) Acute phase proteins as markers of infection and inflammation: monitoring animal health, animal welfare and food safety. Irish Vet J 53: $307-11$.

11. Eckersall PD, Bell R (2010) Acute phase proteins: Biomarkers of infection and inflammation in veterinary medicine. Vet J 185: 23-7.

12. Schneider A, Corrêa MN, Butler WR (2013) Acute phase proteins in Holstein cows diagnosed with uterine infection. Res Vet Sci 95: 269-71.

13. Gronlund U, Hulten C, Eckersall PD, Hogarth C, Persson Waller K (2003) Haptoglobin and serum amyloid A in milk and serum during acute and chronic experimentally induced Staphylococcus aureus mastitis. J Dairy Res 70: 379-86.

14. Baghshani H, Nazifi S, Saeb M, Saeb S (2010) Influence of road transportation on plasma concentrations of acute phase proteins, including fibrinogen, haptoglobin, serum amyloid A, and ceruloplasmin, in dromedary camels (Camelus dromedarius). Comp Clin Pathol 19: 193-8.

15. Gokce G, Citil M, Gunes V, Atalan G (2004) Effect of time delay and storage temperature on blood gas and acid-base values of bovine venous blood. Res Vet Sci 76: 121-7.

16. Gonzalez FH, Tecles F, Martínez-Subiela S, Tvarijonaviciute A, Soler L, et al. (2008) Acute phase protein response in goats. J Vet Diagn Invest 20: 580-4.

17. El-Deeb, W, Tharwat M (2015) Lipoprotein profile, acute phase proteins, proinflammatory cytokines and oxidative stress biomarkers in sheep with pneumonic pasteurellosis. Comp Clin Pathol 24: 581-8.

18. Tharwat M, Al-Sobayil F (2015) Influence of periparturient period on the serum concentrations of inflammation biomarkers in goats. Global Veterinaria 14: 97-102.

19. SPSS (2009) Statistical Package for Social Sciences. Chicago, IL, USA: SPSS, Inc. Copyright for Windows, version 18.0.

20. Sigaard-Andersen O, Fogh-Andersen N (1995) Base excess or buffer base (strong ion difference) as measure of non-respiratory acid-base disturbance. Acta Anaesthesiol Scand 107: 123-8.

21. Pung DG, Baird AN (2011) Sheep and Goat Medicine ( $2^{\text {nd }}$ Edn) Saunders, USA.

22. Yazwinski M, Milizio JG, Wakshlag JJ (2013) Assessment of serum myokines and markers of inflammation associated with exercise in endurance racing sled dogs. J Vet Intern Med 27: 371-6.

23. Murata H (2007) Stress and acute phase protein response: an inconspicuous but essential linkage. Vet J 173: 473-4. 
24. Tharwat M, Al-Sobayil F, Buczinski S (2014) Influence of racing on the serum concentrations of acute-phase proteins and bone metabolism biomarkers inracing greyhounds. Vet J 202: 372-7.

25. Ali A, Derar D, Tharwat M, Zeitoun MM, Al-Sobayil FA (2016) Dystocia in dromedary camels: Prevalence, forms, risks and hematobiochemical changes. Anim Reprod Sci 170: 149-56.

26. Tharwat M, Al-Sobayil F (2015) Serum concentrations of acute phase proteins and bone biomarkers in female dromedary camels during the periparturient period. J Camel Pract Res 22: 271-8.

27. Tharwat M, Al-Sobayil F (2015) The impact of racing on serum concentrations of acute-phase proteins in racing dromedary camels. Comp Clin Pathol 24: 575-9.

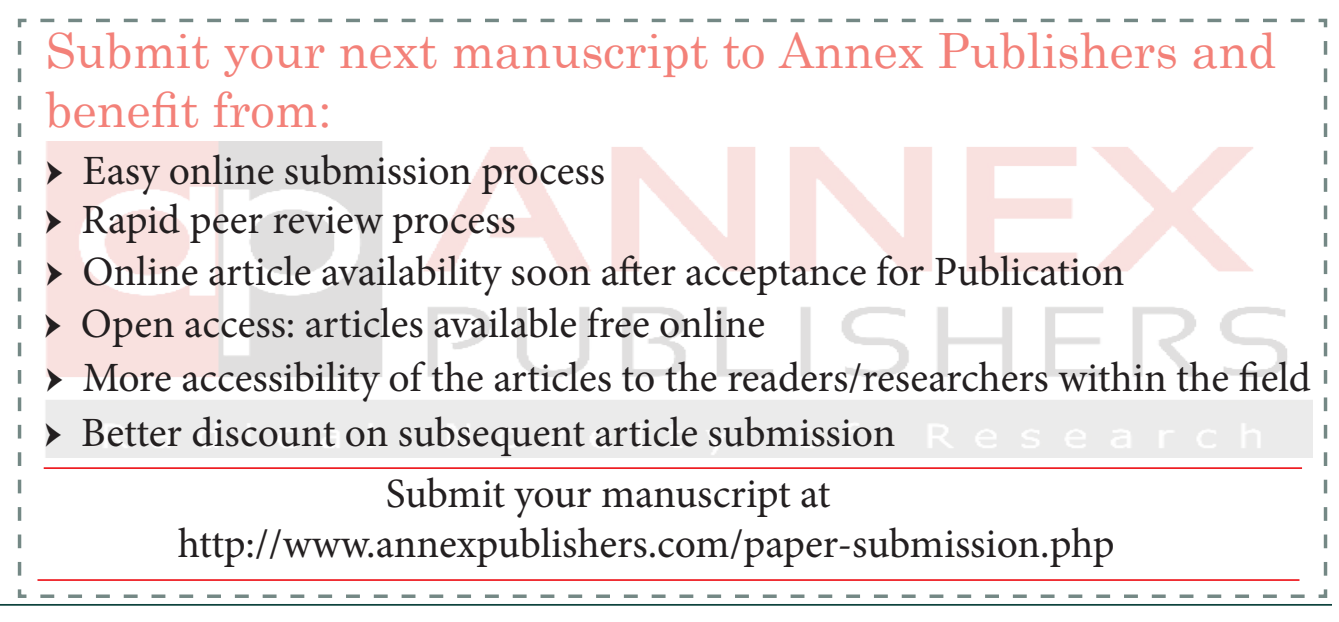

